\begin{tabular}{|c|c|c|c|c|c|c|c|c|}
\hline No. & Glacier name & \multicolumn{2}{|c|}{ Coordinates } & $\begin{array}{c}\text { Length } \\
\mathrm{km}\end{array}$ & $\begin{array}{l}\text { Area } \\
\mathrm{km}^{2}\end{array}$ & $\begin{array}{c}\text { Rale } \\
\text { m year }^{-1}\end{array}$ & Interval & Source \\
\hline 163 & Gangotri & $30.93^{\circ} \mathrm{N}$ & $79.07^{\circ} \mathrm{E}$ & 30.0 & & - & 1850-79 & Shi and others (1988) \\
\hline 164 & Jabula & \multicolumn{2}{|c|}{ Himalaya } & 21.0 & 76.09 & - & $1969-76$ & Shi and others (1988) \\
\hline 165 & Kungbu & \multicolumn{2}{|c|}{ Himalaya } & 18.0 & 39.24 & - & $1930-56$ & Shi and others (1988) \\
\hline 166 & Gechongba & \multirow{2}{*}{\multicolumn{2}{|c|}{$\begin{array}{l}\text { Himalaya } \\
\text { Himalaya }\end{array}$}} & 20.0 & 80.83 & - & 1959-79 & Shi and others (1988) \\
\hline 167 & Bula & & & & & - & 1959-79 & Shi and others (1988) \\
\hline
\end{tabular}

\title{
ERRATUM
}

Vol. 41, No. 139, p. 541

We apologise for misspelling R.J. Motyka's name in the paper by Nolan and others. The correct form is given below.

\section{Ice-thickness measurements of Taku Glacier, Alaska, U.S.A., and their relevance to its recent behavior}

\author{
MatT Nolan, \\ Geophysical Institute, University of Alaska-Fairbanks, Fairbanks, Alaska 99775-7320, U.S.A.
}

Roman J. MOTyka,

Department of Natural Resources, Division of Geological and Geophysical Surveys, Fairbanks, Alaska 99709-3645, U.S.A.

Keith Echelmeyer,

Geophysical Institute, University of Alaska-Fairbanks, Fairbanks, Alaska 99775-7320, U.S.A.

Dennis C. Trabant

U.S. Geological Survey, Water Resources Division, Fairbanks, Alaska 99708, U.S.A. 